\title{
Implementation of Citizenship Education (Community Civic) to Build Citizens Awareness in Developing Local Culture
}

\author{
Hamdi Abdullah Hasibuan ${ }^{1, *}$, Suwarma Al Muchtar², Iim Siti Masyitoh ${ }^{3}$ \\ 1,2,3 Universitas Pendidikan Indonesia, Bandung, Indonesia \\ ${ }^{*}$ Corresponding author. Email:hamdihasibuan20@upi.edu
}

\begin{abstract}
This study is based on the existence of a local culture that is increasingly experiencing degradation, slowly being replaced by technology. Interesting against traditional local cultures that are displaced by the technology is modern, practical, and attractive. So that people care less about their own culture and become individualistic and consumptive. Meanwhile, local culture in the community structure has its proportion to be able to shape the character of citizens. The existence of NGOs in innovation in building awareness of citizens is oriented to local cultural values. This study aims to provide insight into how the implementation of citizenship education (community civics) in the pulled development of local culture. This study uses a qualitative approach with the case study method. Data collection using interviews, observation, and document studies were then analyzed utilizing data reduction, data display, verification, and concluding. The study found that citizenship education (community civics) acts to transform social character in various activities to the social problems that occur. The involvement of citizenship education (community civics) with the development of local culture can build citizen's awareness of local values. NGOs can help the development of local culture by utilizing the individual or community to become actively involved. In this activity, a dynamic process is formed through action and interaction. Community support for the development of local culture has a key in shaping the stability and identity of a character.
\end{abstract}

Keywords: Awareness of Citizens, Community Civic, Local Culture, NGOs.

\section{INTRODUCTION}

The importance of promoting and developing local culture is an obligation for the entire community. The existence of local culture slowly fades during people's lives. The fading of the existence of local culture in the community is influenced by the individualistic attitude of the community, does not have awareness of their own culture, lacks information and knowledge, is more interested in foreign cultures, the influence of technology and globalization [1]. Moreover, society has an individualist and consumptive personality. As a result, local culture in the community is lost, and local culture can be exploited [2].

This situation is a problem in itself to promote and develop local culture. The decline from the existence of local culture has changed the view that citizen involvement and awareness are the keys. Citizens do not become objects but become subjects to develop local culture along with the times. In line with Undang-Undang 5 Tahun 2017 concerning the Advancement of Culture, it is stated that the involvement of citizens has its portion in efforts to promote and develop culture [3]. The process of building the awareness of citizens to be actively involved be a dynamic process to achieve collective knowledge. Citizen awareness to be involved can have a positive impact on the development and sustainability of local culture [4].

Local culture has its substance for each dimension of society. Local culture has the proportion of being a reflection of the identity and personality of the nation. On the other side, local culture may be to suggest a study to prioritize the elements of wisdom, oriental, and civility as well as to establish the character of citizens [4]. In the aspect of local culture, it forms the identity and personality of the nation. At the same time building 
citizen awareness to create citizens with character. Then it leads to one study, namely citizenship education [5].

Citizenship education has an important role in shaping the character of the nation and fostering citizens to become citizens who understand their duties and responsibilities in the life of society, nation, and state [6]. Citizenship education as a sociocultural domain. That is, understanding citizenship must lead to non-formal education. By involving community members who are gathered in a community, NGOs, and civil society movements.

The educational function provided by NGOs can be in the form of providing information, real movements in the community, as well as public participation so that they can build public awareness. At the same time, it can shape the pattern of behavior and lifestyle of citizens. The actions and attitudes of citizens in developing culture can also be seen as a positive impact of these movements and make culture the basis for learning civic education [7].

This research has formulated questions is, (1) How is the implementation of community citizenship education in developing local culture.

\section{THEORETICAL REVIEW}

\section{A. Community Civic}

Community civicis one of a branch citizenship education that emphasizes the relationship between the individual and the social environment, society understands as series of community that is successively hasexpanded community, locality, country, and nationality [8].

In Indonesians, community civic is closer to the term civil society. This is characterized by the contribution of the community or society and non-state citizenship in achieving goals [9]. Community civic will also explore the other side of the problems in society. Interpret the community civic namely by looking at the individual into unity and can practice citizenship. Its form is found in Non-Governmental Organizations (NGOs), communities, and mass media [10].

The purpose of community civic education is to focus learning on social or life conditions related to the scope of the region [20]. Community civic directs citizens to get involved in social issues. Community civic education takes place in non-formal education that occurs in the community, whether carried out by NGOs, communities, or civil society movements [22].

Education and social citizenship provide space for the development of the nation's personality. Community citizenship education forms a smart and good citizen pattern of society [11]. In building a human civilization that is oriented to the development of the nation's personality within the scope of social citizenship, there must be a strategic and systematic effort [23]. This effort is carried out by the government, community organizations, and others. in instilling civic knowledge in society.

In general, social civic education is defined as the transformational relationship of civic knowledge in social life to carry out its duties and responsibilities as citizens directly. Community citizenship education is part of the development of citizenship education or broader citizenship education. This is the sociocultural domain of citizenship education [11].

Citizenship education has the aim of fostering citizens. It is hoped that through this facility formed citizens who have character and become human beings who are responsible for society, nation, and state [6].

\section{B. Citizen Awareness}

Civic education is a study that functions as a means of fostering national character (nation and character building) and empowering citizens. In addition, civic education directs citizens to think critically, creatively, and responsively to citizenship issues. Participate actively and responsibly in the life of society, nation, and state. In this regard, Civics is the most strategic vehicle to raise citizens' awareness of the problems in their social environment [12].

Civic education directs citizens to have knowledge, attitudes, and behavior based on values, norms, and morals. Thus, every citizen is directed to have a collective knowledge of the surrounding social problems. So that self-awareness arises along with knowledge of the rights and obligations as citizens [12].

\section{Local Culture}

Local culture is a cultural value from the past (intangible heritage) which originates from local cultures in the archipelago, including traditions, folklore, and legends, mother tongue, oral history, creativity (dance, song, drama performances), the ability to adaptability and uniqueness of the local community [13].

Local culture, in practice, still lives in the community and is agreed to be a guide in carrying out life [24]. Local culture does not only contain values, and the results of traditional activities and ancestral heritage. However, all of the prevailing cultural components have become characteristics to develop in certain community groups. In this perspective, it is related to the opinion that suggests that local culture is a human effort to maintain the entity that determines the dignity of an individual and his group [14].

The protection of local culture is believed to have an ideological content, namely a campaign to strengthen 
culture, history, and identity, as well as a campaign to encourage public awareness to encourage cultural development. Local culture experiences growth and development in a certain society or tribe because this is an ancestral heritage that must be preserved [25]. The characteristics of the local culture are recognized in the form of social institutions owned by an ethnic group. Talking about local cultural characteristics means talking about an internalized value system.

\section{METHODS}

This study uses a qualitative approach with a case study method [15]. In this study, purposeful sampling was used to determine the source of the data. Purposeful sampling is a technique to determine sources who are considered to be able to provide data [16]. The resource persons in this study were members of the NGO Cultural Foundation Rancage Bandung.

This study uses observation, interviews, and document studies as techniques in collecting data. After the data is collected then the data is analyzed using data reduction, data display, verification, and conclusion [17].

MSWord. The font in the row header should be bold and you can use the style available from the style palette.

\section{RESULT \& DISCUSSION}

Rancage Cultural Foundation is one of the NGOs engaged in the development of local culture. This NGO has a concentration in research and development of local culture. This NGO is open to everyone to be involved in cultural issues. The decline in the existence of regional cultures is of particular concern tobe developed. Developing local culture in this NGO is a culture that is almost forgotten that culture was introduced back and adapted to the times. In its analysis, this NGO sees that cultural conditions are declining every year. So when you see that culture must be maintained in its original state, of course, that culture will experience a decline in interest. However, if culture can be developed along with the demands of the times, then culture can develop and be more varied. This will allow every citizen to see again that culture can be adapted to circumstances.

By definition, local culture is defined as a mother's culture or indigenous culture which is a cultural characteristic of a community group in behaving or interacting in society. For NGOs, the Rancage Cultural Foundation views that the roots of that culture should not be lost. Because this is the foundation of a culture that exists. However, the form of culture can change according to the demands and developments of the times. So rancage has strengthened the cultural roots by setting and formulating the main issues of the local culture. By holding 2 (two) international conferences on Sundanese culture. Then to preserve the roots of that culture, Rancage gives awards to people who have contributed to the field of culture. In addition, this NGO involves residents to attend every cultural activity that takes place.

To build people's awareness of local culture, the rancage has guided residents through its programs. The findings in developing local culture areas listed in the following table:

Table I. Findings in Developing Local Culture Through the NGO, Rancage Cultural Foundation

\begin{tabular}{|c|c|}
\hline Finding & Description \\
\hline $\begin{array}{l}\text { Building } \\
\text { Awareness }\end{array}$ & $\begin{array}{l}\text { (1) Providing information and } \\
\text { knowledge about local cultural } \\
\text { conditions; (2) providing } \\
\text { socialization and cultural } \\
\text { campaigns to residents; (3) } \\
\text { bringing residents to be involved } \\
\text { in cultural activities such as arts, } \\
\text { traditions, and traditional } \\
\text { ceremonies. }\end{array}$ \\
\hline $\begin{array}{l}\text { The involvement of } \\
\text { several elements in the } \\
\text { existence of local culture }\end{array}$ & $\begin{array}{l}\text { It should be understood that the } \\
\text { involvement of several of these } \\
\text { elements is very important for } \\
\text { the return of the existence of } \\
\text { local culture. (1) involvement of } \\
\text { NGO members and the } \\
\text { community; (2) the role of the } \\
\text { younger generation is seen from } \\
\text { the spirit; and } \quad \text { (3) utilizing } \\
\text { technology }\end{array}$ \\
\hline $\begin{array}{l}\text { Patterns of local cultural } \\
\text { development in the } \\
\text { community }\end{array}$ & $\begin{array}{l}\text { The pattern found in developing } \\
\text { local culture can be done in } 2 \\
\text { ways, namely: (1) establishing a } \\
\text { special institution that focuses } \\
\text { on research on regional } \\
\text { cultures; (2) perpetuating } \\
\text { information about local cultures } \\
\text { into websites or websites; and } \\
\text { (3) holding a cultural } \\
\text { conference. }\end{array}$ \\
\hline $\begin{array}{l}\text { Implementation } r \text { of } \\
\text { Community } \\
\text { Education }\end{array}$ & $\begin{array}{l}\text { (1) In the implementation of } \\
\text { activities carried out by NGOs on } \\
\text { cultural development, it is seen } \\
\text { that the attitude of responsibility } \\
\text { and awareness of citizens is } \\
\text { visible. (2) the independence and } \\
\text { responsibility that arise are } \\
\text { characters that arise from the } \\
\text { habituation process that occurs. }\end{array}$ \\
\hline
\end{tabular}

Explanation of Table I, Pattern coaching done is to provide information and knowledge on the widest 
condition, and situations culture. In this case the provision of information and knowledge by inviting people who are experts in the field of culture. This is done to provide actual knowledge to every citizen to foster a love of their own culture.

In the next stage, providing socialization and cultural campaigns to residents. The socialization was carried out to strengthen the awareness of the residents that local culture has more meaning in the joints of life. Cultural campaigns are carried out to instill knowledge to all elements of society, both young and old, to continue to maintain every wisdom that is around because it is a national identity. Such treatments are carried out consistently to confront citizens in real terms about the conditions of culture and existence.

By bringing residents to be involved in every cultural activity, be it arts, traditions, traditional ceremonies, thus slowly growing awareness of citizens to care and bind to their local culture. When analyzed it is clear the local culture has a significant role in the community. Preserving, empowering, and developing local culture is an obligation and responsibility to all elements. Citizens' awareness and responsibility can grow if the guidance is carried out correctly and continuously. Cooperation must be carried out by the government, schools, mass media, NGOs, and other communities.

Rancage presents for non-governmental organizations (NGOs) working in the field of culture. Rancage itself is open to everyone to be involved in cultural issues and their development. For rancage, local culture is essential for the community. It is a pity if the people themselves do not have any concern for culture. Because the meaning contained in culture can be a means of education. On the other side, based on the concept of community civic, the contribution that can be made to realize social change, increase participation, knowledge, has grown in every NGO rancage activity. Where every activity intersects with the community. The purpose of caring for culture is one of preserving the activities of RampakGendang, WayangGolek, Baduiculture, and others who are expected to know each culture. Therefore, rancage movements are by community civic.

Efforts to develop local culture through NGO planning can be carried out by utilizing the younger generation and technology. The role of the younger generation is expected to be able to encourage young people to increase their love of local culture. The younger generation through his involvement is very important because creativity and high spirits are expected to continue and expand the right culture. In reality, the younger generation can encourage them to create a socio-cultural life that is by development. Utilizing technology is also part of the effort to preserve local culture. Pancasila is a reference in utilizing technological advances so that it has an impact on the realization of community welfare. technology becomes another strategy in developing local culture [18]. In practice, various platforms can be used to introduce local cultures so as not to lose their identity. By utilizing technology, it is possible to develop a local culture to be more contemporary so that it is more easily accepted for generations.

To develop local culture, Table I found several patterns of local cultural development. Establish a special institution that focuses on research on regional cultures. With the existence of this special institution, it will be easier to explore the root causes of cultural problems. And make it easier to get a solution and will appear thinkers who are concerned in the field of local cultural development. Capture information about culture into sites or websites. The point is to make it easier to dig up information and knowledge about local cultures. Hold a cultural conference. Thus, it is useful to know the development of local culture from all parts of Indonesia.

When viewed from the aspect of Citizenship Education. Civics has a relationship with local culture. It can be seen that the object of civics study and civic education is citizens about social, social, economic, religious, cultural, and state organizations [8]. By substantial science, civic education grows and develops by the social development of society, and can also play a role in efforts to develop a nation's cultural identity.

Based on Permendikbud No. 59 Tahun 2014 regarding the study of local culture and cultural identity is discussed in the fourth point, namely Bhineka Tunggal Ika. The context of diversity will reduce the tendency of regional characteristics that arise from the wisdom values of each region. Local culture and cultural identity are part of Bhineka Tunggal Ika. So Civics is a discipline that directs critical, rational, creative, responsible thinking, interacting with other nations, as well as character building. The process of forming national character can be pursued in several ways, including by paying attention to the local culture owned by the community which has the potential to contribute to the success of the development of the nation's cultural identity or personality [19].

The concept of citizenship education (community civic) is a process of transforming the values of the nation's character in society which is applied in various community activities to solve various social problems that occur. Through citizenship education, every citizen is required to become an independent and responsible citizen $[11,6]$. Independent citizens are those who do not depend on others to complete every task. While responsibility is having the knowledge and skills to understand and solve various problems with appropriate and good decisions [11].

In the implementation of citizenship education, it was 
found that in the implementation of activities carried out by NGOs in the development of local culture, there was an attitude of responsibility from the awareness of the citizens. The concern that is seen in carrying out rancage activities is a form of realizing civic community. It is also a process of forming the character of citizens to be responsible. Each individual builds a paradigm related to the problems faced and is faced with demands to solve problems regarding local culture. So this process becomes the independence of the nation which is realized as a result of the actions taken.

In the analysis, the activities carried out by rancage as a civic community has shown an attitude of independence and responsibility as a form of community citizenship education. This can be seen from the enthusiasm and consistency in carrying out activities to maintain the existence of local culture to remain. So at this stage, the awareness of citizens has emerged. The success of rancage activities is considered to be able to provide benefits not only to rancage institutions but to all elements of society to get involved and participate. Thus, the results obtained have changed the view of local culture which declined and then turned into a positive one due to the awareness that emerged to develop it to be more innovative.

The independence and responsibility that emerge are characters that arise from the habituation process that occurs. So this character needs to be nurtured to become an attitude in everyday life. This character development through the civic community can be done by using methods of habituation, example, and social movements. To maintain it, prioritize civic education as the spearhead of education in the socio-cultural domain.

In addition to the development of national character, local cultural development activities have encouraged the achievement of existing expectations. This activity is carried out solely to raise public awareness to be involved in raising the existence of local culture in the current global era. These movements are oriented towards the belief that local culture can revive and can change the behavior of citizens by the values of wisdom contained in local culture. At the same time, it changes the social order in society [21].

So, social citizenship education must continue to be developed within the community in the form of community activities. Through various NGOs or community groups to provide a broad understanding to the community related to the social problems they face. The orientation of the civic community is based on the values of national identity that are sourced from the local culture. These values represent the character that emerges from society. At the same time transforming the values of the character of the nation's identity in society.

\section{CONCLUSION}

The process of implementing citizenship education (community civic) in building citizen awareness in developing local culture has shown a good process in the social order of the community. This can be seen from the enthusiasm of the residents to be involved in local cultural development activities. Through NGOs, the rancage cultural foundation becomes a means to build citizen awareness to be involved in a real and actual way. This involvement is the result of a long process carried out. This series of processes has shown that the implementation of civic community can be carried out properly. Likewise, the NGO cultural foundation rancage has provided innovations in solving social problems for local culture.

\section{ACKNOWLEDGMENTS}

I would like to express my gratitude to all NGO members who are willing to become informants. And to all parties involved in this research, I would like to say thank you very much for their help so that this research can be completed properly.

\section{REFERENCES}

[1] WikaHardikaLegiani, Ria Yunita Lestari, H, Hermeneutika,Jurnal Hermeneutika, vol. 4(1), 2018, pp. 37-46. https:/jurnal.untirta.ac.id/index.php/Hermeneutik a

[2] Mubah, A. S, Revitalisasi Identitas Kultural Indonesia di Tengah UpayaHomogenisasi Global, Jurnal Global Dan Strategis, Vol 5(No3), 2011, pp. 251-260. http://www.journal.unair.ac.id/filerPDF/7 SafrilRevitalisasi Identitas Kultural Indonesia di Tengah UpayaHomogenisasi Global, ok.pdf

[3] Undang-Undang Nomor 5 Tahun 2017 tentang Pemajuan Kebudayaan

[4] Mahardika, I. W. T., \&Darmawan, C, Civic Culture DalamNilai-NilaiBudaya Dan KearifanLokalMasyarakat Bali Aga DesaTrunyan, Humanika, vol23(1), 2016, pp. 20. DOI: https://doi.org/10.14710/humanika.23.1.2031

[5] Akbal, M, Pendidikan Kewarganegaraan dalam Pembangunan Karakter Bangsa, Gadjah Mada University Press Bekerja sama Dengan LAN RI., vol 1(1), 2016, pp. 485-493.

[6] Rohani, Urgensi Pembinaan Tanggung jawab Warga, Sosial Horizona, Jurnal Pendidikan Sosial, vol. 2(2), 2016, pp. 221-234. DOI: http://doi.org/10.31571/sosial.v2i2.107

[7] Rizky, R. N, Lembaga Sosial Masyarakat, Media Massa dan HakAnak, JURNAL SIMBOLIKA: 
Research and Learning in Communication Study, vol3(2), 2018, pp. 87. DOI: https://doi.org/10.31289/simbollika.v3i2.1454

[8] Wahab dan Sapriya. Teori Dan Landasan Pendidikan Kewarganegaraan. Bandung: Alfabeta CV. 2011

[9] Mawarti \& Sundawa, PERANAN CIVIC COMMUNITY DALAM MENDORONG PEMUDA SEBAGAI PELOPOR KEMANDIRIAN BANGSA (Studi kasus pada komunitas "Pasukan Kresek" di Kabupaten Malang JawaTimur),Nurani, vol. 16(2), 2016, pp. 63-84. DOI: https://doi.org/10.19109/nurani.v16i2.934

[10] Hidayati, D, Memudarnya Nilai Kearifan Lokal Masyarakat Dalam Pengelolaan Sumber Daya Air (WANING VALUE OF LOCAL WISDOM IN THE MANAGEMENT OF WATER RESOURCES, Jurnal Kependudukan Indonesia|, 11(Juni), 2016, pp. 39-48. http://ejurnal.kependudukan.lipi.go.id/index.php/ jki/article/viewFile/36/62

[11] Sutrisno, S, Pendidikan Kewarganegaraan Kemasyrakatan Dalam Membangun Wawasan Warga Negara Global, Jurnal Pendidikan Kewarganegaraan, vol. 10(2), 2020, pp. 53. DOI: https://doi.org/10.20527/kewarganegaraan.v10i2. 8000

[12] Darsono, B, Menumbuhkan kesadaran berkonstitusi di lingkungan sekolah melalui pendidikan kewarganegaraan, Jurnal Harmoni, vol. 1(1), 2017, pp. 14-29.

[13] Karmadi, A, Budaya Lokal Sebagai Warisan Budaya Dan Upaya Pelestarian, Dialog Budaya Daerah Jawa Tengah, 2007, pp. 1-6

[14] Geertz, Clifford. Islam Observed Religious Development in Marocco and Indonesia. United States of America: Phoenix Editio. 2016

[15] Sugiyono. Metode Penelitian Bisnis (Pendekatan Kuantitatf, Kualitatif dan R\&D). Bandung: Alfabeta CV. 2014

[16] Creswell, Jhon W. Riset Pendidikan: Perencanaan, Pelaksanaan, dan Evaluasi Riset Kualitatif Dan Kuantitatif. Yogyakarta: PustakaPelajar. 2015

[17] Ali, Mohammad. Memahami Riset Perilaku Dan Sosial. Jakarta: BumiAksara. 2014

[18] Hasibuan, H. A., \& Simatupang, E, Peran tradisi boteng tunggul dalam memperkuat civic culture masyarakat adat lombok, voll8, 2021, pp. 1936.

DOI: https://doi.org/10.24114/jk.v18i1.22620

[19] Peraturan Menteri Pendidikan Dan Kebudayaan Nomor 59 Tahun 2014 tentang Kurikulum 2013 Sekolah Menegah Atas/Madrasah Aliyah
[20] Winataputra, U. S. \& Budimansyah. Pendidikan Kewarganegaraan Dalam Perspektif Internasional (konteks, Teoridan Profil Pembelajaran). Bandung: Widya Aksara Pers. 2012

[21] Boyle, R., \& Kelly, L. W, Commentary: Television, business entertainment, and civic culture,Television and New Media, vol. 14(1), 2013, pp. 62-70. DOI: https://doi.org/10.1177/1527476411435420

[22] Cutlip, A. C., Bankston, W. B., \& Lee, M. R, Civic community and nonmetropolitan white suicide,Archives of Suicide Research, vol.14(3), 2010, pp. 261-265. DOI: https://doi.org/10.1080/13811118.2010.494145

[23] Ousey, G. C., \& Lee, M. R, Whose civic community? Testing alternative hypotheses of the relationship between civic community and racial inequality in arrest rates,Sociological Spectrum, vol. 30(5), 2010, pp. 550-579. DOI: https://doi.org/10.1080/02732173.2010.496104

[24] Gobang, J. K. G. D, Konflik Budaya Lokal Pada Masyarakat Di Pulau Flores (Sebuah Analisis Komunikasi Lintas Budaya), Jurnal Komunikasi, vol. 9(1), 2014, pp. 59-68. DOI: https://doi.org/10.20885/komunikasi.vol9.iss1.art 5

[25] Sandoval-Rivera, J. C. A, Environmental education and indigenous knowledge: Towards the connection of local wisdom with international agendas in the framework of the Sustainable Development Goals (SDGs),Diaspora, Indigenous, and Minority Education, vol. 14(1), 2020, pp. 14-24. DOI: https://doi.org/10.1080/15595692.2019.1652588 